\title{
High quality RNA isolation from ployphenol-, polysaccharide- and protein-rich tissues of lentil (Lens culinaris)
}

\author{
Prasanta K. Dash
}

Received: 3 May 2012/Accepted: 1 June 2012/Published online: 24 June 2012

(C) The Author(s) 2012. This article is published with open access at Springerlink.com

\begin{abstract}
Current RNA isolation methods have limitations in their ability to yield good quality and quantity of RNA from plants that have high content of phenols, polysaccharides and storage proteins. Existing methods also do not eliminate accompanying chromosomal DNA in RNA preparation that causes false positives in gene expression studies. Standard isolation technique was modified for rapid and quick extraction of RNA, and lentil tissue most appropriate to extract good quality RNA was determined. The concentration of the phenol blocker polyvinylpyrrolidone in the extraction buffer was determined, DNase I was added to eliminate chromosomal DNA and the timing of this step was optimized. RNA up to $568 \mu \mathrm{g}$ of RNA from $1 \mathrm{~g}$ of tissue was isolated from four different tissues of lentil in less than half the time typically required by reported methods. The method avoids the use of toxic phenol-chloroform, hazardous guanidinium thiocyanate (GTC) and laborious $\mathrm{CsCl}$ ultracentrifugation. Absorbance A260/A280 ratio of 1.9 and A260/A230 ratio of 2.7 reveal RNA to be of high purity. Modified method yielded RNA that was free from contaminants and suitable for RT-PCR and cDNA library construction.
\end{abstract}

Keywords RNA isolation - Polysaccharide ·

Polyphenols · Lipids · PCR analysis - RT-PCR analysis · Gene library $\cdot$ Lentil $\cdot$ Legumes

\section{Abbreviations \\ PCR Polymerase chain reaction}

P. K. Dash $(\bowtie)$

NRC on Plant Biotechnology, IARI, LBS Building,

PUSA Campus, New Delhi 110012, India

e-mail: prasanta01@yahoo.com
RT-PCR Reverse transcription-Polymerase chain reaction

DEPC Diethylpyrocarbonate

$\mathrm{KCl}$ Potassium chloride

$\mathrm{LiCl} \quad$ Lithium chloride

cDNA Complimentary DNA

DNase Deoxy-ribonuclease

$\mu \mathrm{L} \quad$ Microlitre

rcf Relative centrifugal force

\section{Introduction}

Lentil (Lens culinaris ssp. culinaris) is a cool-season grain legume cultivated throughout world and in Indian subcontinent providing a vital source of dietary protein in human diets and straw for animal feed. It is a diploid ( $2 n=2 \times=14)$, annual flowering self-pollinating crop with a genome size of $4 \mathrm{Gbp}$ (Kaur et al. 2011). In terms of genomic resources, lentil has relatively limited available data, in comparison to other Fabaceae species. A total of 9675 EST sequences and 485 GSS sequences in lentil are present in the public domain as of 17 December, 2011 as compared to 42,578 ESTs; 50,853 GSSs in chickpea (Gujaria et al. 2011) and 23914 ESTs; 89301 GSSs in pigeonpea including the whole genome sequence (Singh et al. 2011). To identify novel genes and provide the community a functional genomics resource that will facilitate research and breeding, there is a significant need to enhance lentil genomic resources. Obtaining high-quality RNA is a crucial requirement in developing genomic resources such as performing gene expression experiments, cDNA library construction, real-time PCR or microarray 
analyses. Theoretically, one copy of chromosomal DNA is sufficient to generate false positives in gene expression and cDNA-based studies, which makes elimination of DNA contamination from RNA extracts essential.

Standard RNA isolation techniques such as guanidinium-phenol-chloroform extraction are reliable for animal tissues, but are generally not applicable to leguminous plant materials (Baker et al. 1990) and specifically unsuitable for lentil plants. Legumes in general and lentil tissues in particular are often rich in polyphenols, polysaccharides and lipids that interfere with or degrade RNA, thus restricting its yields and deteriorating the quality. Polyphenols limit RNA extraction as they become oxidised to quinones, which covalently bind to nucleic acids (Mattheus et al. 2003). Polysaccharides display similar physicochemical properties to RNA (Azevedo et al. 2003; Sharma et al. 2003), and coprecipitate with and contaminate RNA extracts (Singh et al. 2003). Lipids associated with proteins and carbohydrates also interfere with RNA isolation protocols. If these macromolecular contaminants are not removed, they lead to erroneous estimations of RNA quantity and interfere with reverse transcription and PCR, thus compromising gene expression studies (Koonjul et al. 1999).

A rapid modified procedure of the established techniques (Chang et al. 1993; Wan and Wilkins 1994; Birtic and Kranner 2006) is described here that overcomes the above difficulties simultaneously and avoids the use of toxic phenol-chloroform and hazardous guanidinium thiocyanate. The protocol is applicable to all types of tissues ranging from root to developing grains of lentil, which are rich in protein, lipid and phenolic compounds. The isolated RNA from all the tissues is amenable for downstream applications such as PCR, RT-PCR and cDNA library construction.

\section{Materials and method}

Plant material, sampling and chemicals

Field grown lentil plants were sampled for root, stem and leaf tissues 45 days after sowing. Developing grains were collected at 15 days post-anthesis. All the explants were immediately snap frozen in liquid nitrogen and stored at $-80{ }^{\circ} \mathrm{C}$ until further use. Mature seeds of lentil were obtained from Pulse Research Laboratory, IARI, New Delhi. Liquid nitrogen frozen explants were freeze dried to remove water so as to avoid chemical reactions during sample handling and storage (Kranner and Grill 1996). The chemicals used were of molecular biology grade and solutions were made with double-distilled water. Consumables were RNase free, plasticware and pipette tips were treated overnight with $0.1 \%$ DEPC-treated distilled water and autoclaved. Mortars and pestles were baked overnight at $140{ }^{\circ} \mathrm{C}$. All centrifugation steps were conducted at $10,000 \mathrm{rcf}$ at $0{ }^{\circ} \mathrm{C}$.

\section{RNA isolation}

The plant materials were finely powdered by grinding in liquid nitrogen and to maintain uniformity $100 \mathrm{mg}$ of fine powder was used as starting material. A modified borax decahydrate extraction buffer was used for the extraction of RNA from all the tissues of lentil. The buffer contained $0.2 \mathrm{M}$ sodium tetraborate decahydrate, $30 \mathrm{mM}$ Methylene glycol tetraacetic acid, $1 \%(\mathrm{w} / \mathrm{v})$ Sarkosyl and $1 \%(\mathrm{w} / \mathrm{v})$ sodium deoxycholate and the $\mathrm{pH}$ was adjusted to 9.0 by the addition of $1 \mathrm{M}$ sodium hydroxide. For each tissue sample, $500 \mu \mathrm{L}$ extraction buffer containing $6 \%(\mathrm{w} / \mathrm{v})$ polyvinylpyrrolidone (PVP) and $0.2 \%(\mathrm{w} / \mathrm{v})$ of the reductant dithiothreitol were added. The mixture was vortexed and incubated at $80^{\circ} \mathrm{C}$ for $5 \mathrm{~min}$. Subsequently, $1 \mathrm{mg}$ of proteinase $\mathrm{K}$ was added to the hot solution and was incubated at $42{ }^{\circ} \mathrm{C}$ for $1 \mathrm{~h}$ after vortexing. To eliminate seed reserves, $50 \mu \mathrm{L} 2 \mathrm{M}$ potassium chloride was added and the samples were incubated on ice for $30 \mathrm{~min}$ followed by centrifugation at $10,000 \mathrm{rcf}$ for $10 \mathrm{~min}$. Approximately, $400 \mu \mathrm{L}$ of the lower aqueous phase was transferred to a new tube. This eliminated the lipids, which are present in the upper phase. Nucleic acids were precipitated by the addition of 0.3 volumes of $120 \mu \mathrm{L}$ of ice-cold $10 \mathrm{M} \mathrm{LiCl}$. After adding $\mathrm{LiCl}$, the suspension colour immediately turned milky white. The sample was incubated at $-80{ }^{\circ} \mathrm{C}$ for $30 \mathrm{~min}$ and again centrifuged for $10 \mathrm{~min}$ at 10,000 rcf. The supernatant was discarded and the pellet was washed with $100 \mu \mathrm{L}$ of $2 \mathrm{M} \mathrm{LiCl}$. The pellet containing nucleic acids was re-suspended in $100 \mu \mathrm{L} \mathrm{T}_{10} \mathrm{E}_{1}$ buffer. An aliquot $(1 \mu \mathrm{L})$ of the supernatant was used for the quantification by taking absorbance at $A 260 \mathrm{~nm}$. To eliminate chromosomal DNA contamination, $10 \mu \mathrm{L}$ DNase I $(10 \mathrm{mg} / \mathrm{ml})$ was added to the solution and incubated at $37{ }^{\circ} \mathrm{C}$ for $30 \mathrm{~min}$. Excess DNase I and contaminating proteins were removed by potassium acetate ( $\mathrm{pH} 4.8)$ and ethnol precipitation.

\section{Quantitation and integrity of total RNA}

The quantity and quality of the RNA obtained were assessed spectrophotometrically at 230, 260 and $280 \mathrm{~nm}$. The $A 260 / 280$ ratio was used to detect the contamination with proteins and $A 260 / 230$ ratio was used to check for carbohydrate contamination. Quality and integrity of isolated RNA was verified by electrophoresing RNA on $1.5 \%$ agarose gel and staining with ethidium bromide (Sambrook et al. 1989). The bands were visualised and photographed using Gel documentation unit. 
cDNA synthesis, RT-PCR and library construction

cDNAs were synthesized using $0.5 \mu \mathrm{g}$ total RNA extracted from lentil roots, stems, leaves and etiolated seedlings by RT-PCR using 1st strand cDNA synthesis Kit (AMV; Roche, UK). The cDNAs were PCR amplified (with expected amplicon of $360 \mathrm{bp}$ ) by lectin gene (NCBI Accession No AY547295) specific primers, a gene reported to encode an insecticidal protein against sap sucking insects. PCR reactions were carried out in a final volume of $25 \mu \mathrm{L}$ reaction mixture containing $10 \mathrm{mM}$ Tris $-\mathrm{HCl}(\mathrm{pH}$ 8.3), $50 \mathrm{mM} \mathrm{KCl}, 1.5 \mathrm{mM} \mathrm{MgCl}_{2}, 200 \mu \mathrm{M}$ dNTP, $0.2 \mu \mathrm{M}$ each primer (forward: 5'-GTCATAGATG CGCCCAGCAG- $3^{\prime}$ and reverse 5'-GTTACATTC TCTTCCTCAA GTG- $3^{\prime}$ ) and $0.5 \mathrm{U}$ of $\mathrm{Taq}$ DNA polymerase. The temperature profile was as follows: initial denaturation at $95{ }^{\circ} \mathrm{C}$ for $4 \mathrm{~min}, 35$ cycles at $94{ }^{\circ} \mathrm{C}$ for $30 \mathrm{~s}, 57^{\circ} \mathrm{C}$ for $30 \mathrm{~s}$, and $72^{\circ} \mathrm{C}$ for $1 \mathrm{~min}$ followed by final extension for 7 min at $72{ }^{\circ} \mathrm{C}$. A 'control PCR' was carried out with $0.5 \mu \mathrm{g}$ of total RNA in the absence of reverse transcriptase to check for chromosomal DNA contamination.

Using $10 \mu \mathrm{g}$ total RNA-isolated from developing seed samples, the cDNA library was constructed with SMART cDNA library construction kit (Clontech, California, USA). The library was subsequently used for screening full-length lectin gene (unpublished data).

\section{Result and discussion}

Standard methods for RNA extraction (Chomczynski and Sacchi 1987; Salzman et al. 1999) could not be used for lentil tissues as they are rich in multiple macromolecular components. Therefore, for isolating nucleic acids from these plants, the general approach was modified so as to prevent the formation of these complexes and remove macromolecular contaminants as quickly as possible. Lowering the temperature is thought to decrease the rate of chemical reactions irrespective of exothermic or endothermic nature of reaction. Thus, we attempted to keep temperature low during RNA extraction. When the temperature was kept at $0{ }^{\circ} \mathrm{C}$ along with the addition of phenol blocker and reducing agents, the phenolic compounds did not react with nucleic acids and were precipitated with other debris after the first centrifugation and the supernatant appeared completely clear.

On the contrary, guanidinium thiocyanate based method, highly successful in the case of animal tissues, did not yield good RNA for lentil tissues. Commercially available kits utilizing magnetic particle separation technique yields high amount of poly $(\mathrm{A})^{+}$mRNA from animal cells, but did not work well with leguminous plants. The yield of RNA isolated from lentil using those kits was much lower than
Table 1 Total RNA yield isolated from different tissues of lentil using borax deca-hydrate protocol

\begin{tabular}{llll}
\hline Plant Tissues & \multicolumn{3}{l}{ Borax decahydrate method } \\
\cline { 2 - 4 } & $\begin{array}{l}\text { RNA Yield } \\
(\mu \mathrm{g} / \mathrm{g} \text { tissue })\end{array}$ & RNA purity & \\
\cline { 3 - 4 } & & A260/A280 & A260/A230 \\
\hline Leaf & $568 \pm 41$ & $1.9 \pm 0.01$ & $2.7 \pm 0.14$ \\
Root & $201 \pm 23$ & $1.73 \pm 0.08$ & $2.6 \pm 0.2$ \\
Stem & $186 \pm 18$ & $1.7 \pm 0.11$ & $2.4 \pm 0.7$ \\
Etiolated seedling & $58 \pm 11$ & $1.86 \pm 0.44$ & $2.3 \pm 0.24$ \\
Developing seed & $4.7 \pm 1.9$ & $1.8 \pm 0.21$ & $1.9 \pm 0.1$ \\
Mature seed & 0 & $\mathrm{ND}$ & $\mathrm{ND}$
\end{tabular}

Data represent mean $\pm \mathrm{SD}$ of three replicates

$N D$ Not determined

that obtained using the protocol described in the present study. The current protocol is a modification of the methods described earlier (Mattheus et al. 2003; Wan and Wilkins 1994). In our study, GTC has been replaced by sodium tetraborate and sarkosyl followed by $\mathrm{LiCl}$ precipitation.

When RNA was isolated by the current method, $568 \mu \mathrm{g}$ of RNA was obtained from $1 \mathrm{~g}$ of leaf tissue followed by $201 \mu \mathrm{g}$ from roots and $186 \mu \mathrm{g}$ from stems. Etiolated seedlings yielded $58 \mu \mathrm{g}$ RNA, while minimum of $4.7 \mu \mathrm{g}$ RNA was obtained from developing seeds (Table 1). The $A 260 / A 280$ and A260/A230 ratios of the RNA extracts were as high as 1.9 and 2.7 , respectively, which indicates the presence of very low amounts of contaminating proteins, polysaccharides and polyphenol compounds. Purity of RNA samples (A260/A230 ratio) isolated from leaves was 1.9, while in case of stem tissues it was 1.7. The bands corresponding to $28 \mathrm{~S}$ and $18 \mathrm{~S}$ rRNA were significantly prominent in RNA extracted from leaves than other tissues indicating amenability of leaf tissues for the isolation of RNA. Gel electrophoresis of RNA samples isolated from all tissues resulted in firm and distinct bands of $28 \mathrm{~S}$ and $18 \mathrm{~S}$ rRNA and showed the RNA to be of excellent quality (Fig. 1; lane R-D). Since matured seeds contain high molecular weight storage proteins along with lipids and polysaccharides, we could not extract any RNA (lane S) from them.

Rapid extraction of high-quality RNA from all of the tissues became possible after resolving the following key concerns: use of low temperature and optimum PVP concentration; removal of excess macromolecular admixtures such as proteins, polysaccharides and lipids and digestion of chromosomal DNA from RNA spool. The experiment was conducted using an extraction buffer with $\mathrm{pH} 9$. However, when the same buffer with $\mathrm{pH} 7$ was used, the yield and quality were less. Poor results were due to the

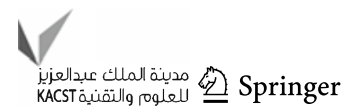




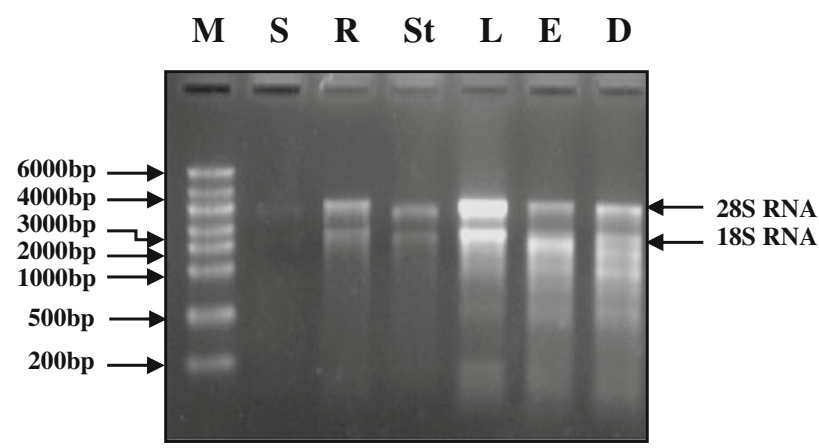

Fig. 1 Isolation of Total RNA from different tissues of lentil. Lane $M$ Riboruler High Range RNA ladder, $S$ mature seed, $R$ root, $S t$ stem, $L$ leaf, $E$ etiolated seedling, $D$ developing seeds

presence of large amounts of contaminants in the plant tissues. In our protocol, an initial extraction in borax buffer removed most contaminants. It provided maximum RNA solubility and removed small endogenous nucleases, which reduce RNA yield and purity by nonspecific RNA aggregation (Kranner and Grill 1996; Wallace 1987).

When the samples were extracted at room temperature, the supernatant appeared brown. This indicated that the phenolic compounds reacted with the nucleic acids. In contrast, when the temperature was kept at $0{ }^{\circ} \mathrm{C}$, the phenolic compounds did not react with nucleic acids and the supernatant was clear. The low temperature not only increased the quantity of RNA but also the quality of RNA (Fig. 2; lane 2,4) by drastically reducing the degradation of RNA. Furthermore, the degradation activity was arrested by the addition of phenol blocker polyvinylpyrrolidone. It forms complexes with polyphenols through hydrogen bonds and allows the polyphenols to be separated from nucleic acids. Similar to low temperature, we found many fold increase in RNA yield by the addition of PVP (Fig. 2; lane 1,3$)$. In case of xerophytic plants that contain exorbitant amount of polyphenols and many times grinding the leaves into fine powder are time-consuming, because they are hard and thick, chemically inert cross-linked form of PVP (PVPP) has been used (Wang et al. 2011). This involves sprinkling of insoluble PVPP directly onto the frozen leaf tissue in the mortar and vigorously grinding leaf tissue in the presence of liquid nitrogen to avoid the oxidation of released polyphenols into quinines, which in turn cannot bind to nucleic acids and hinder the isolation of high quality RNA. For lentil tissues, we found that the optimum concentration of PVP was $6 \%(\mathrm{w} / \mathrm{v})$ that blocked and precipitated the phenolics with other debris and the supernatant appeared completely clear after the first centrifugation. Although, some plant RNA isolation protocols prefer to use insoluble polyvinylpyrrolidone (Shukla et al. 2005), our experience with leguminous plants has shown that soluble polyvinylpyrrolidone is more effective in

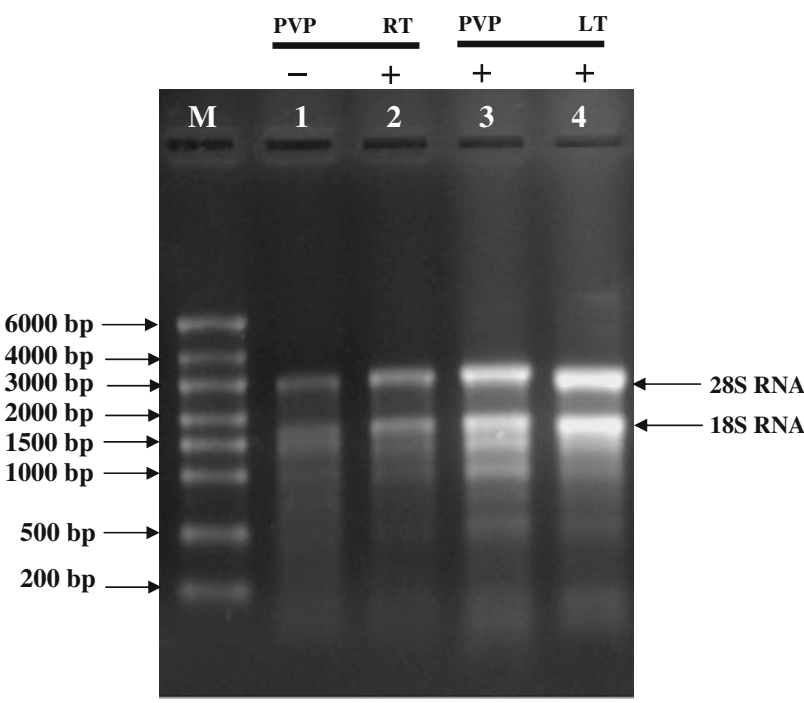

Fig. 2 Isolation of total RNA from leaf with and without PVP and in room temperature and low temperature. Lane $M$ riboruler High Range RNA ladder, lane 1 total RNA from leaf without PVP (-), lane 2 total RNA from leaf in room temperature (RT), lane 3 total RNA from leaf with PVP $(+)$, lane 4 total RNA from leaf in low temperature (LT)

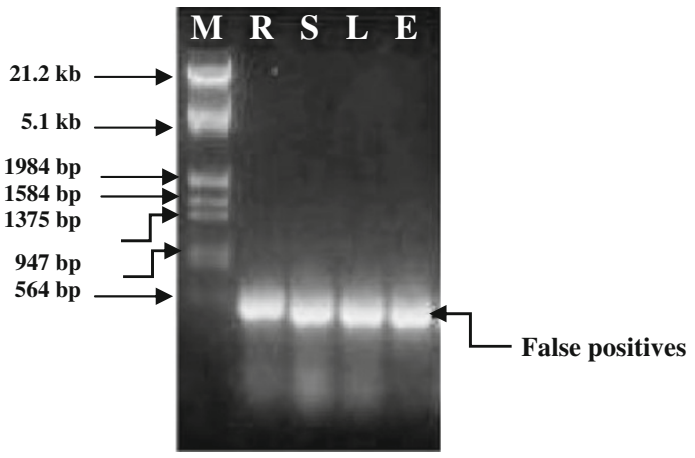

Fig. 3 False positive PCR amplification of lectin gene using total RNA without DNase1 treatment. $\mathrm{M}=\lambda E c o \mathrm{R} 1+$ HindIII DNA Marker, $R$ root, $S$ stem, $L$ leaf; $E$ etiolated seedling

countering the problem arising due to the presence of phenolic compounds.

DNase I was applied to eliminate contaminating genomic DNA in RNA samples (Huang et al. 1996). Since the addition of DNase I at the end of the RNA isolation procedure affects the migration of RNA in the agarose gel, it was applied immediately after precipitation with lithium chloride. Excess DNase I was later deactivated and removed by acidification and centrifugation. The necessity for the use of DNase I was confirmed by running a control PCR. RNA samples, to which DNase I was not applied showed gene amplification (false positives), indicating that RNA preparation is contaminated with genomic DNA (Fig. 3; R-E). In contrast, samples treated with DNase I showed only primer dimers but no gene amplification, 


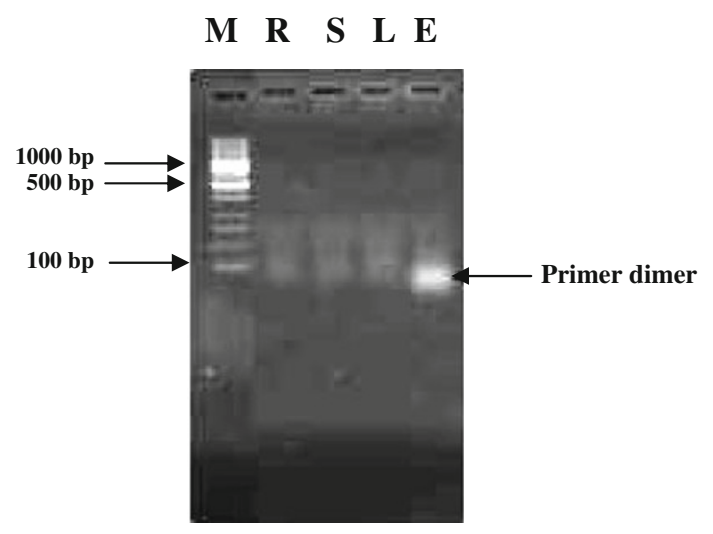

Fig. 4 PCR amplification (showing primer dimmer) of lectin gene using DNase 1 treated total RNA. $\mathrm{M}=100 \mathrm{bp}$ DNA ladder, $R$ root, $S$ stem, $L$ leaf, $E$ etiolated seedling

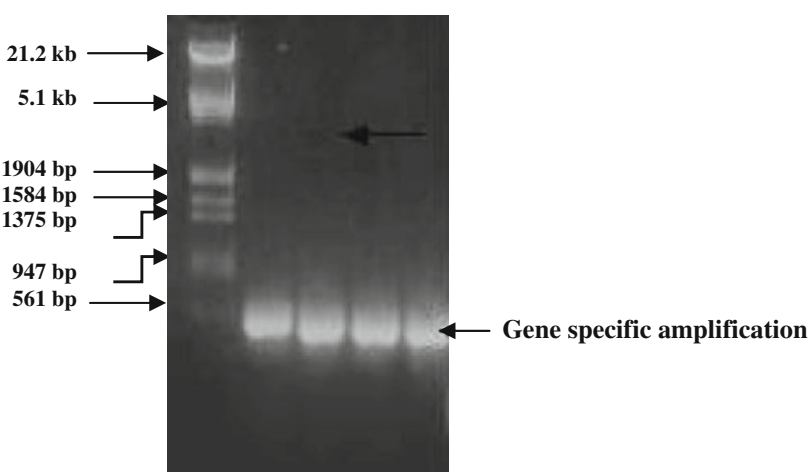

Fig. 5 RT-PCR amplification of lectin gene using DNase 1 treated total RNA. M $=\lambda E c o$ R1 + HindIII DNA Marker, $R$ root, $S$ stem, $L$ leaf, $E$ etiolated seedling

demonstrating that the isolated RNA was free from genomic DNA (Fig. 4; R-E).

The above described method allows for the extraction of sufficient quantities of high-quality RNA in a much shorter time (4 $\mathrm{h}$ as compared with $18 \mathrm{~h}$ ) than previously reported. This was achieved mainly by taking small amount of tissues and reducing the time required for the precipitation of nucleic acids with lithium chloride. A short precipitation time of $1 \mathrm{~h}$ resulted in an excellent quality of RNA. Overall, the described method achieved more than adequate yields for RT-PCR purposes. Therefore, reverse transcription followed by standard PCR was used to test RNA quality. After extraction of RNA from roots, stems, leaves, etiolated seedlings, cDNA was prepared by reverse transcription. Further, the single stranded cDNA was used as a template in standard PCR with gene specific primers to amplify an expected amplicon of $360 \mathrm{bp}$ of lectin gene. Successful amplification of lectin amplicon (AY547295) from all RNA preparations (Fig. 5; R-E) indicates that the isolated RNA is of good quality and amenable for down stream applications such as cDNA synthesis and RT-PCR.
Using total RNA isolated from leaves of lentil, a cDNA library was constructed with a titre of $3.5 \times 10^{6} \mathrm{cfu}$, which is a good target library. The library was rich in full-length cDNA and we were able to isolate a full-length transcript (972 bp) through library screening approach (unpublished data).

\section{Conclusion}

Unlike pre-existing protocols for phenolic tissues (Salzman et al. 1999; Woodhead et al. 1997; Gehrig et al. 2000), in the proposed procedure, PVP was used in combination with low temperature to circumvent the problem of phenolic compounds. In addition, no special chemicals such as GTC-based buffer or phenol-chloroform-isoamyl alcohol are necessary. This protocol is simple, fast and inexpensive to perform, allowing efficient extraction of high-quality RNA from lentil, a plant rich in macromolecular contaminants. The RNA is free of contaminating DNA and is suitable for downstream applications such as reverse transcription, gene amplification and gene library construction. The new protocol is also suitable for isolating RNA from other plant species and tissues that are devoid of phenolic compounds and thus expected to be widely applicable.

Acknowledgments The author acknowledges Project Director, NRPCB for the facility and resources provided to carry out the research. Help of Ms Payal Gupta, Mr R N Gupta in preparation of solutions, and critical reading of manuscript by Dr Rhitu Rai is gratefully acknowledged.

Open Access This article is distributed under the terms of the Creative Commons Attribution License which permits any use, distribution, and reproduction in any medium, provided the original author(s) and the source are credited.

\section{References}

Azevedo H, Lino-Neto T, Tavares RM (2003) An improved method for high-quality RNA isolation from needles of adult maritime pine trees. Plant Mol Biol Rep 21:333-338

Baker SS, Rugh CL, Kamalay JC (1990) RNA and DNA isolation from recalcitrant plant tissues. Biotechniques 9:268-272

Birtic S, Kranner I (2006) Isolation of high quality RNA from polyphenol-, polysaccharide- and lipid-rich seeds. Phytochem Anal 17:144-148

Chang S, Puryear J, Cairney J (1993) A simple and efficient method for isolating RNA from pine trees. Plant Mol Biol Rep 11:113116

Chomczynski P, Sacchi N (1987) Single step method of RNA isolation by acid guanidine isothiocynate phenol chloroform extraction. Anal Biochem 162:156-159

Gehrig HH, Winter K, Cushman J, Borland A, Taybi T (2000) An improved RNA isolation method for succulent plant species rich in polyphenols and polysaccharides. Plant Mol Biol Rep 18:369-376 
Gujaria N, Kumar A, Dauthal P, Dubey A, Hiremath P, Bhanu Prakash A, Farmer A, Bhide M, Shah T, Gaur PM, Upadhyaya HD, Bhatia S, Cook DR, May GD, Varshney RK (2011) Development and use of genic molecular markers (GMMs) for construction of a transcript map of chickpea (Cicer arietinum L.). Theor Appl Genet 122(8):1577-1589

Huang ZQ, Fasco MJ, Kaminsky LS (1996) Optimization of DNase I removal of contaminating DNA from RNA for use in quantitative RT-PCR. Biotechniques 20:1012-1020

Kaur S, Cogan NO, Pembleton LW, Shinozuka M, Savin KW, Materne M, Forster JW (2011) Transcriptome sequencing of lentil based on second-generation technology permits large-scale unigene assembly and SSR marker discovery. BMC Genomics 12:265-275

Koonjul PK, Brandt WF, Farrant JM, Lindsey GG (1999) Inclusion of polyvinylpyrrolidone in the polymerase chain reaction reverses the inhibitory effects of polyphenolic contamination of RNA. Nucl Acids Res 27:915-916

Kranner I, Grill D (1996) Determination of glutathione and glutathione disulphide in lichens: a comparison of frequently used methods. Phytochem Anal 7:24-28

Mattheus N, Ekramoddoullah AKM, Lee SP (2003) Isolation of highquality RNA from white spruce tissue using a three-stage purification method and subsequent cloning of a transcript from the PR-10 gene family. Phytochemical Anal 14:209-215

Salzman RA, Fujita T, Zhu-Salzman K, Hasegawa PM, Bressan RA (1999) An improved RNA isolation method for plant tissues containing high levels of phenolic compounds or carbohydrates. Plant Mol Biol Rep 17:11-17

Sambrook J, Fritsch EF, Maniatis T (1989) Extraction, purification and analysis of messenger RNA from eukaryotic cells. In: Molecular cloning a laboratory manual, second edn. Cold Spring Harbor Laboratory Press, Cold Spring Harbor, p 7.1

Sharma AD, Gill PK, Singh P (2003) RNA isolation from plant tissues rich in polysaccharides. Anal Biochem 314:319-321

Shukla AK, Shasany AK, Khanuja SP (2005) Isolation of poly (A)+ mRNA for downstream reactions from some medicinal and aromatic plants. Indian J Exp Biol 43(2):197-201

Singh G, Kumar S, Singh P (2003) A quick method to isolate RNA from wheat and other carbohydrate-rich seeds. Plant Mol Biol Rep 21:93a-93f

Singh NK et al (2011) The first draft of the pigeonpea genome sequence. J Plant Biochem Biotech 21(1):98-112

Wallace DM (1987) Large- and small-scale phenol extractions. Meth Enzymol 12:33-48

Wan CY, Wilkins TA (1994) A modified hot borate method significantly enhances the yield of high-quality RNA from cotton (Gossypium hirsutum L). Anal Biochem 223:7-12

Wang X, Xiao H, Chen G, Zhao X (2011) Isolation of high-quality RNA from Reaumuria soongorica, a desert plant rich in secondary metabolites. Mol Biotechnol 48:165-172

Woodhead M, Taylor MA, Davies HV, Brennan, McNicol RJ (1997) Isolation of RNA from blackcurrant (Ribes nigrum L.) fruit. Mol Biotechnol 7(1):1-4 